\title{
Know How to Regrow-Axon Regeneration in the Zebrafish Spinal Cord
}

\author{
Vasiliki Tsata $^{1, *}$ and Daniel Wehner ${ }^{2,3, *(\mathbb{D})}$ \\ 1 Experimental Surgery, Clinical and Translational Research Center, Biomedical Research Foundation Academy \\ of Athens, 11527 Athens, Greece \\ 2 Max Planck Institute for the Science of Light, 91058 Erlangen, Germany \\ 3 Max-Planck-Zentrum für Physik und Medizin, 91058 Erlangen, Germany \\ * Correspondence: vtsata@bioacademy.gr (V.T.); daniel.wehner@mpl.mpg.de (D.W.)
}

Citation: Tsata, V.; Wehner, D. Know How to Regrow-Axon Regeneration in the Zebrafish Spinal Cord. Cells 2021, 10, 1404. https://doi.org/ $10.3390 /$ cells10061404

Academic Editor:

Antón Barreiro-Iglesias

Received: 29 April 2021

Accepted: 4 June 2021

Published: 6 June 2021

Publisher's Note: MDPI stays neutral with regard to jurisdictional claims in published maps and institutional affiliations.

Copyright: (c) 2021 by the authors. Licensee MDPI, Basel, Switzerland. This article is an open access article distributed under the terms and conditions of the Creative Commons Attribution (CC BY) license (https:/ / creativecommons.org/licenses/by/ $4.0 /)$.

\begin{abstract}
The capacity for long-distance axon regeneration and functional recovery after spinal cord injury is poor in mammals but remarkable in some vertebrates, including fish and salamanders. The cellular and molecular basis of this interspecies difference is beginning to emerge. This includes the identification of target cells that react to the injury and the cues directing their pro-regenerative responses. Among existing models of successful spinal cord regeneration, the zebrafish is arguably the most understood at a mechanistic level to date. Here, we review the spinal cord injury paradigms used in zebrafish, and summarize the breadth of neuron-intrinsic and -extrinsic factors that have been identified to play pivotal roles in the ability of zebrafish to regenerate central nervous system axons and recover function.
\end{abstract}

Keywords: zebrafish; spinal cord injury; axon regeneration; functional recovery

\section{Introduction}

The inability of severed axonal fibres to regrow across the lesion site after spinal cord injury (SCI) prevents recovery of locomotor function and results in permanent functional deficits in humans. The severity and level of the injury define a broad range of symptoms. These include partial to complete loss of sensory and locomotor function, sexual, bowel and bladder function impairments, heart, breathing and blood pressure dysregulation and chronic pain. To date, no effective treatment exists that can reverse the pathology, which has debilitating consequences for affected individuals [1]. Hence, enabling long-distance growth of spinal cord connections after injury to achieve substantial functional recovery remains one of the greatest challenges in regenerative medicine. During embryonic and neonatal stages some mammals such as mice and opossum [2-4], birds [5] and anuran amphibians [6] can regrow central nervous system (CNS) axons. However, with the possible exception of the African spiny mouse [7], in all of these cases developmental age alters the regenerative capacity of the CNS, which sharply declines after birth and is eventually lost. Contrary to mammals, many aquatic species including urodele amphibians (axolotl, newt) [8,9] and fish such as carp [10], eel [11], lamprey [12,13], goldfish [14] and zebrafish [15] exhibit a remarkable regenerative capacity that persists to adulthood and throughout the CNS, including the brain [16], spinal cord [15] and the visual system [17-19]. Although a holistic understanding of the mechanisms underlying successful CNS regeneration in these species is still elusive, important cellular and molecular players have been identified. Deepening insights on neuron-intrinsic and -extrinsic factors facilitating functional regeneration in regeneration-competent species could be potentially leveraged for the development of novel therapeutic approaches in humans. In this review, we focus on zebrafish, which due to their genetic amenability and excellent optical properties at larval stages, have provided a mechanistic insight on how the spinal cord can be successfully repaired after injury. In particular, we will focus on the events identified to facilitate axonal 
regrowth of axotomized neurons - the pre-requisite for functional restoration after SCI. It is important to note that besides axon regeneration, zebrafish respond to SCI with robust regenerative neurogenesis, which was expertly reviewed elsewhere [20,21].

\section{Axon Regeneration and Functional Recovery after SCI in Zebrafish}

Similar to mammals, following an injury to the spinal cord, zebrafish are initially paralyzed caudal to the lesion site. However, they successfully recover most of their swimming activity within a few days (larva) or weeks (adult) [22-25]. It is well documented that restoration of swimming function critically depends on the regrowth of axonal projections across the lesion site. When axonal regrowth was experimentally hindered through creation of a physical barrier at the lesion site, functional recovery was absent [22]. Similarly, zebrafish larvae that failed to form axonal connections (bridge) between the severed spinal cord ends exhibited markedly worse recovery of swimming distance [26]. Re-transection of regenerated spinal cords abolished the restored swimming activity in both systems, underlining the necessity of axon regeneration for functional recovery [24,27].

\section{Differential Regenerative Capacity of Zebrafish Axons}

Although much less is known about the composition of regrowing axons in larval as compared to adult zebrafish, research over the last few decades has revealed a differential regenerative capacity among different neuronal subtypes. This depends on the level of axotomy (distance from the soma), the size/length of the neuronal projection, as well as the direction of the axonal tract (descending, ascending). Early experiments using the neural tract-tracing technique (anterograde and retrograde axonal tracing) showed that spinal cord transection severs descending axons from 20 distinct brain nuclei, ascending axons to the brainstem as well as intraspinal descending and ascending axons [15]. The majority of brain nuclei regrow axons beyond the transection site into the distal spinal cord [15,22,28,29]. However, brain nuclei are distinct in their regenerative capacity such as the nucleus of the medial longitudinal fascicle (nMLF) or the nucleus of the lateral lemniscus, which can be viewed as good and poor regenerators, respectively [30]. Although greatly altered as compared to pre-injury levels, dopaminergic $\left(\mathrm{TH}^{+}\right)$and serotonergic $\left(5-\mathrm{HT}^{+}\right)$terminals are also re-established [27]. Finally, intraspinal neurons have been reported to extend axons across the lesion site [31], which includes a very low number of ascending tracts [30]. In larval zebrafish, a systematic analysis on the regenerating axonal subtypes after SCI is currently missing as studies have mainly used pan-neuronal markers to label neurites. However, both long descending projections from the brainstem such as the nMLF axons, which control swimming function [32], as well as axons from intraspinal neurons (e.g., $m n x 1^{+}, v s x 2^{+}$), appear to robustly contribute to the axonal bridge (D. Wehner, T. Becker, C. G. Becker; unpublished observations; [33]). Interestingly, while reticulospinal Mauthner axons seem to fail to regenerate in the adult zebrafish [15], their robust regeneration was reported by some studies in larval animals to depend on the level of axotomy along the rostro-caudal axis [34-36]. Of note, with the exception of the Mauthner axons [34], which have been directly linked to a short latency escape response in larval animals [37], the contribution of individual axons to functional recovery after SCI remains to be investigated. Collectively, a great body of research has demonstrated that larval and adult zebrafish axons successfully regenerate after SCI. Although anatomical regeneration of the spinal cord is imperfect [31,38-40], regrown axons innervate appropriate targets, which suffices for functional restoration $[22,24]$.

\section{A Breadth of Zebrafish SCI Paradigms}

SCI models are mainly categorized according to: (i) the injury mechanism, (ii) the site of the injury and, (iii) the model organism used. In mammals, SCI paradigms usually involve an acute injury such as contusion, compression, dislocation and transection or a graded damage, such as distraction (stretching) and chemical injury, while injury levels vary from lumbar, to cervical and thoracic level. Several injury models have been also 
developed in zebrafish. Yet, the difference to mammals is robust axonal regrowth and functional recovery.

\subsection{Mechanical Lesion}

Among the injury paradigms frequently used is a mechanical lesion. In larval zebrafish the spinal cord is completely transected at the level of the urogenital pore through an incision using either sharp glass [36,41] or an injection needle [24,42]. Alternatively, a stab lesion has been employed [26,43]. Lesioning abolishes swimming function, which is restored within a few days after the injury [24,25].

In adult zebrafish, a mechanical lesion to the spinal cord is inflicted by a complete transection, approximately $5 \mathrm{~mm}$ caudal to the brainstem-spinal cord junction, which corresponds to a midthoracic level injury [15]. As in the larval model, this injury paradigm leaves no axons spared at the lesion site and provides an optimal platform to study axon regeneration. Alternatively, a crush injury in which forceps compress the spinal cord at the level of the 15-16th vertebrae, causes axonal degeneration without resulting in complete transection and assimilates an injury mode occurring in humans [44]. In both cases, fish are paralyzed caudal to the injury site, yet recovery of swimming activity typically occurs within $6-8$ weeks post-lesion $[22,23]$.

\subsection{Alternative Lesion Paradigms}

In addition to mechanical lesions, a variety of cell ablation paradigms have been used to investigate axon regeneration in zebrafish. The Nitroreductase (NTR)/Metronidazole (MTZ) system [45] provides a pharmacogenetic platform to selectively ablate spinal neurons within hours of treatment and to monitor their fast regeneration within 2 days [24]. To overcome the dependence of such an approach on the availability of tissue-specific promoters, an optogenetic system was developed that utilizes a photoactivatable GAVPO transactivator element to light-inducible drive expression of the cytotoxic ion channel variant $\mathrm{M} 2{ }^{\mathrm{H} 37 \mathrm{~A}}$ [46]. Furthermore, electroablation has been used to induce localized spinal damage [47]. The latter relies on the application of an electrical pulse and allows the investigation of axon regeneration after neurectomy. Finally, spinal cord lesions and selected axotomy of trigeminal sensory axons have been reported utilizing a 2-photon microscope with a focused high-power laser [48,49]. Overall, a plethora of different injury paradigms have confirmed the high regenerative capacity of the zebrafish spinal cord and provide a variety of systems to dissect the mechanistic underpinnings of successful axonal regrowth Due to the rapid regeneration time and optical accessibility for live imaging, the larval model offers an ideal platform to study the dynamics of cellular interactions in the injured spinal cord. Adult fish are better suited when analyzing processes that are not fully developed in larvae, such as the adaptive immune response, or when more complex behavioral readouts are needed.

\section{Neuron-Extrinsic and -Intrinsic Factors Define Successful Axon Regeneration in Zebrafish}

SCI in mammals results in: (i) neuronal and glial cell loss, (ii) activation of the immune system and, (iii) rapid recruitment of non-neuronal cells, such as fibroblasts, to the lesion site. The cellular events that follow the initial damage caused by the primary impact create a regeneration-limiting zone $[50,51]$ that further develops and expands over time, inhibiting axonal regrowth and functional recovery (Figure 1). To date, several neuron-intrinsic (e.g., cytoskeleton disorganization, impaired transport of retrograde signals) and -extrinsic ("environmental") factors (e.g., inflammation, scarring) have been identified to contribute to the failure of axonal regrowth after SCI in mammals. In sharp contrast, zebrafish CNS axons possess a high intrinsic capacity for regenerative growth, which in combination with a permissive environment, promotes axon regeneration beyond the lesion site and enables functional recovery [52] (Figure 1). 

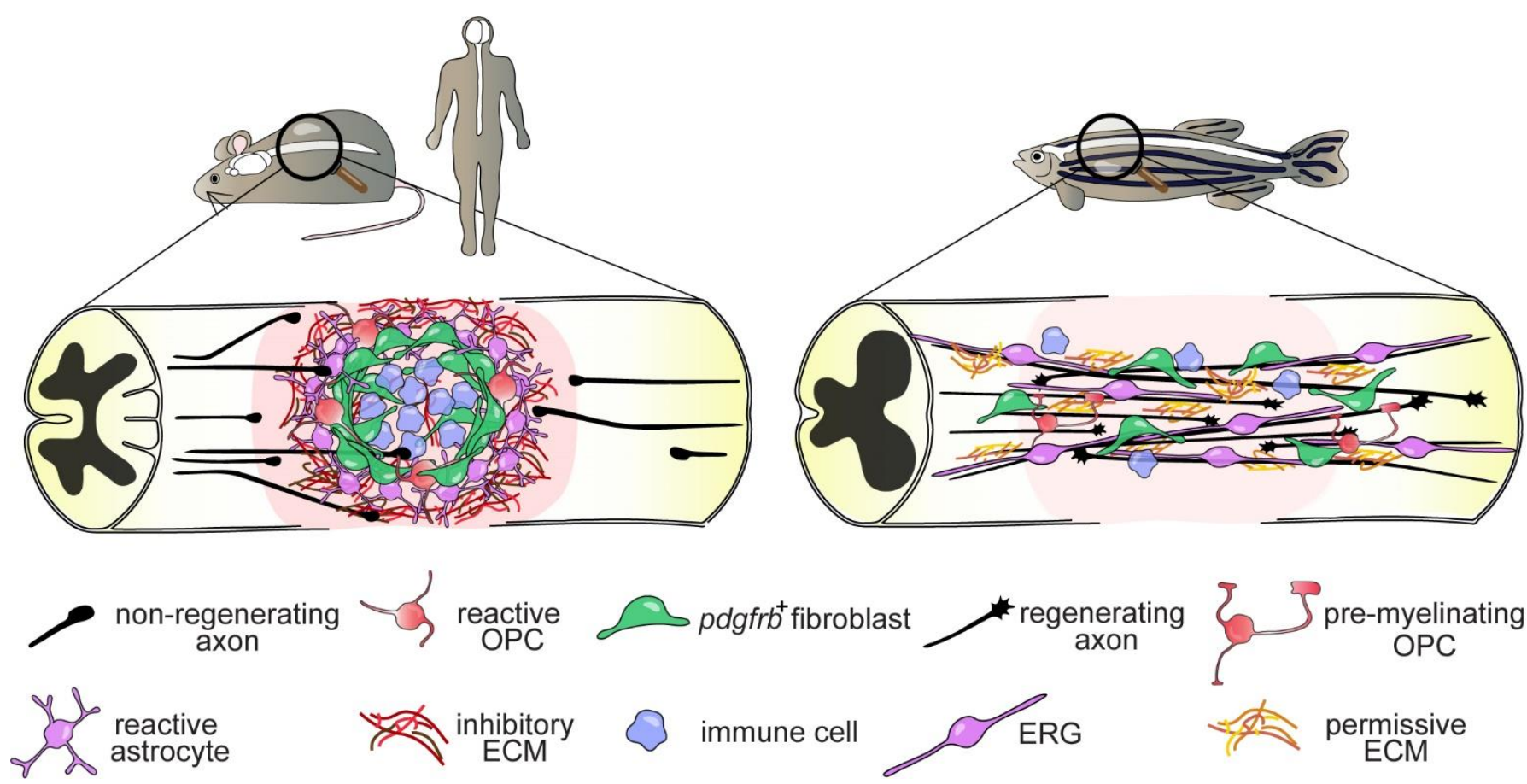

Figure 1. Differential regenerative capacities of the mammalian and zebrafish spinal cord. In mammals, a complex injury scar is formed by invading immune cells and $p d g f r b^{+}$fibroblasts, as well as reactive OPCs and astrocytes, which constitutes a hostile environment to axon growth. Although these cell types respond in a similar manner to SCI in zebrafish, they do not contribute to the formation of an injury scar. Instead, reactive cells promote axonal regrowth (bridging) across the lesion site. Shown are major target cells underlying the different fate in either species. Abbreviations: OPC, oligodendrocyte progenitor cell; $p d g f r b^{+}$, platelet-derived growth factor receptor $\beta$-positive; ECM, extracellular matrix; ERG, ependymo-radial glia.

\subsection{Immune System}

Activation of resident microglia and the release of pro-inflammatory cytokines such as interleukins (IL) IL- $1 \mathrm{~b}, \mathrm{IL}-6$ and tumor necrosis factor $\alpha$ (TNF- $\alpha$ ) are among the early events occurring within the first minutes to hours after SCI in mammals $[53,54]$. Together with the invasion of peripheral neutrophils, macrophages and T-lymphocytes that infiltrate the injury site in a time-dependent response [55], the persistent activation of the immune system leads to a prolonged inflammatory phase that participates in lesion propagation and contributes to a hostile environment that inhibits axonal regrowth [56]. Substantial evidence indicates that in the zebrafish spinal cord, acute inflammation is necessary and sufficient for axonal regrowth $[24,57,58]$ (Figure 1). After injury, a timed response of consecutively appearing neutrophils and macrophage/microglia occurs. During this phase, immune cells are found to be closely associated with and/or engulf cellular and myelin debris, indicating clearance of the latter [29,57]. Interestingly, increasing cellular debris levels in the lesion site through interference with phagocytosis did not impair axon regeneration, similar to what has been suggested for the regeneration of the optic nerve in mice [59]. This suggests that phagocytosis and removal of cellular debris are of rather minor importance to axon regeneration [57]. Suppression of microglia, macrophage and neutrophil responses by dexamethasone treatment impaired regeneration, indicating a promoting role of innate immune cells in axonal regrowth and functional recovery after SCI [57,58]. Analyses of interferon regulatory factor 8 (irf8)-deficient mutants that lack macrophages and microglia but not neutrophils, revealed a biphasic role of inflammation on axon regeneration. A transient upregulation of proinflammatory cytokines Il- $1 \beta$ and Tnf- $\alpha$ is beneficial rather than detrimental to the regenerative capacity of axons [57]. This proinflammatory phase needs to be tightly controlled though, as its prolongation by genetic depletion of macrophages or loss-of-function of the anti-inflammatory cytokine transforming growth factor beta-1 (tgfb1a), inhibits regeneration $[57,60]$. Of note, in larval zebrafish, microglia appear to 
play a rather negligible role in promoting axon regeneration as compared to peripheral macrophages. In addition to the innate immune response, the adaptive immunity is crucial for axon regeneration in adult zebrafish. T regulatory cells infiltrate the injured spinal cord and secrete regeneration-promoting factors, such as neurotrophins (neurotrophin-3; Ntf3), and their targeted ablation impairs axonal growth and recovery of swimming activity [61]. Together, the precise timing and regulation of the immune response after SCI critically contributes to the creation of a regeneration-permissive environment in zebrafish and highlights potential components of the injury-induced cellular reactions that may be targeted in non-regenerating mammals (Figures 2 and 3). Notably, the immune system-derived factor TNF- $\alpha$, which was identified as critical for regeneration in zebrafish [57], has also been highlighted as target for therapeutic intervention after SCI in humans [62]. This supports the relevance of the zebrafish model for translational spinal cord regeneration research.

A

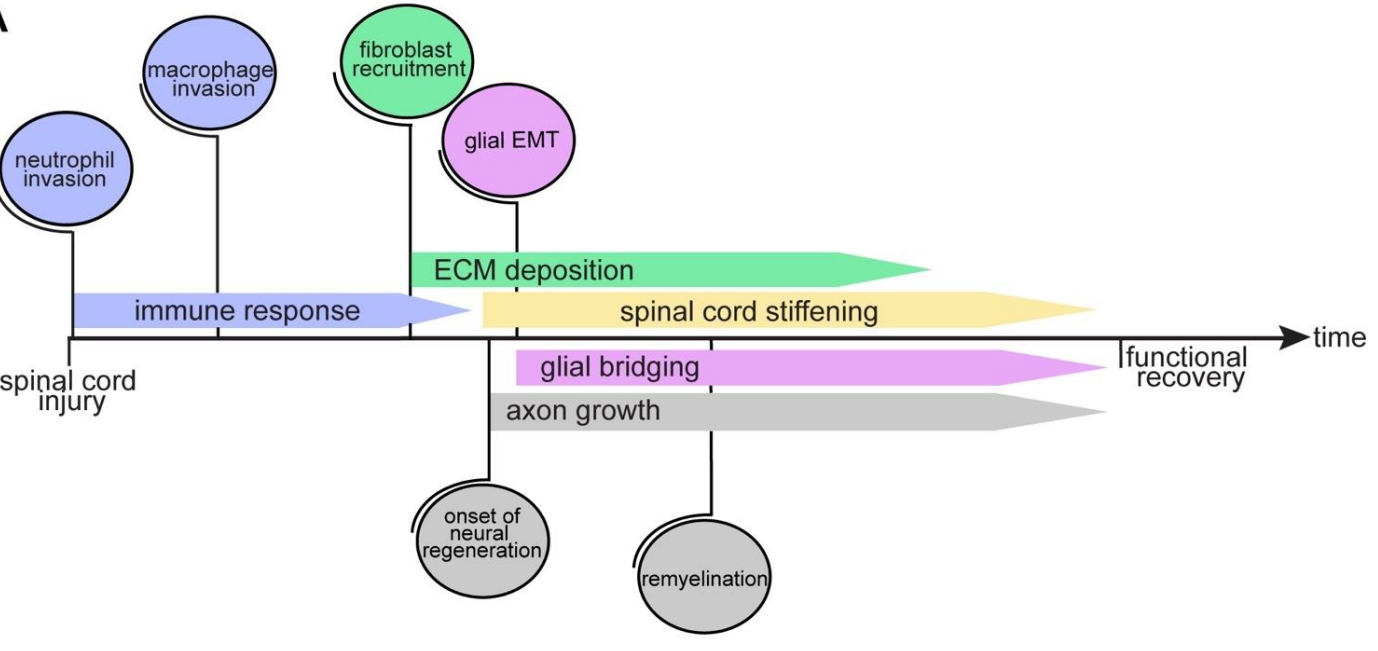

B

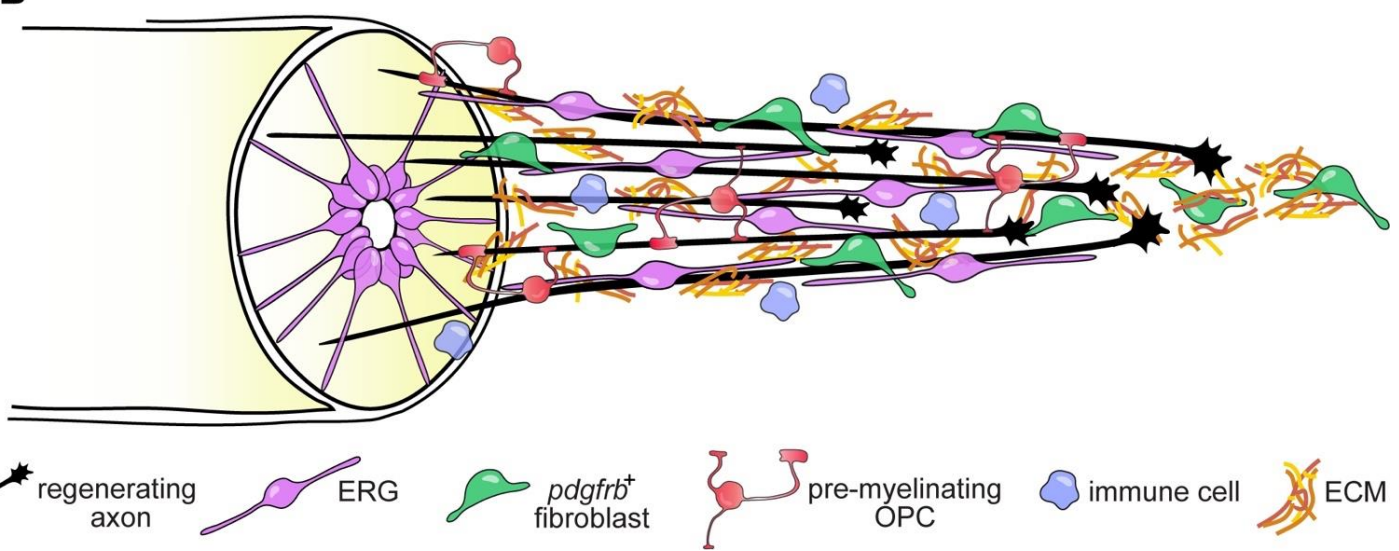

Figure 2. Cellular responses and events facilitating axon regeneration after SCI in zebrafish. An injury to the zebrafish spinal cord induces an immediate yet transient immune response mediated by activation of both resident microglia as well as invasion of peripheral neutrophils and macrophages. This is followed by the recruitment of $p d g f r b^{+}$fibroblasts that deposit a growth-permissive ECM. Axons navigate the ECM-rich lesion environment. ERGs undergo an epithelial-to-mesenchymal transition (EMT) and participate in the formation of a neural tissue bridge that reconnects the severed spinal cord. Reactive OPCs differentiate into pre-myelinating OPCs that will remyelinate regrowing axonal fibres. The roles of individual reactive cells are described in detail in the main text. The sequence of events and the spatial relationship of major cellular components involved in axonal regrowth are summarized in (A) and (B), respectively. Note that no specific timepoints are given as the schematic view summarizes recent findings obtained from studies in larval and adult zebrafish. Abbreviations: EMT, epithelial-to-mesenchymal transition; ERG, ependymo-radial glia; $p d g f r b^{+}$, platelet-derived growth factor receptor $\beta$-positive; OPC, oligodendrocyte progenitor cell; ECM, extracellular matrix. 


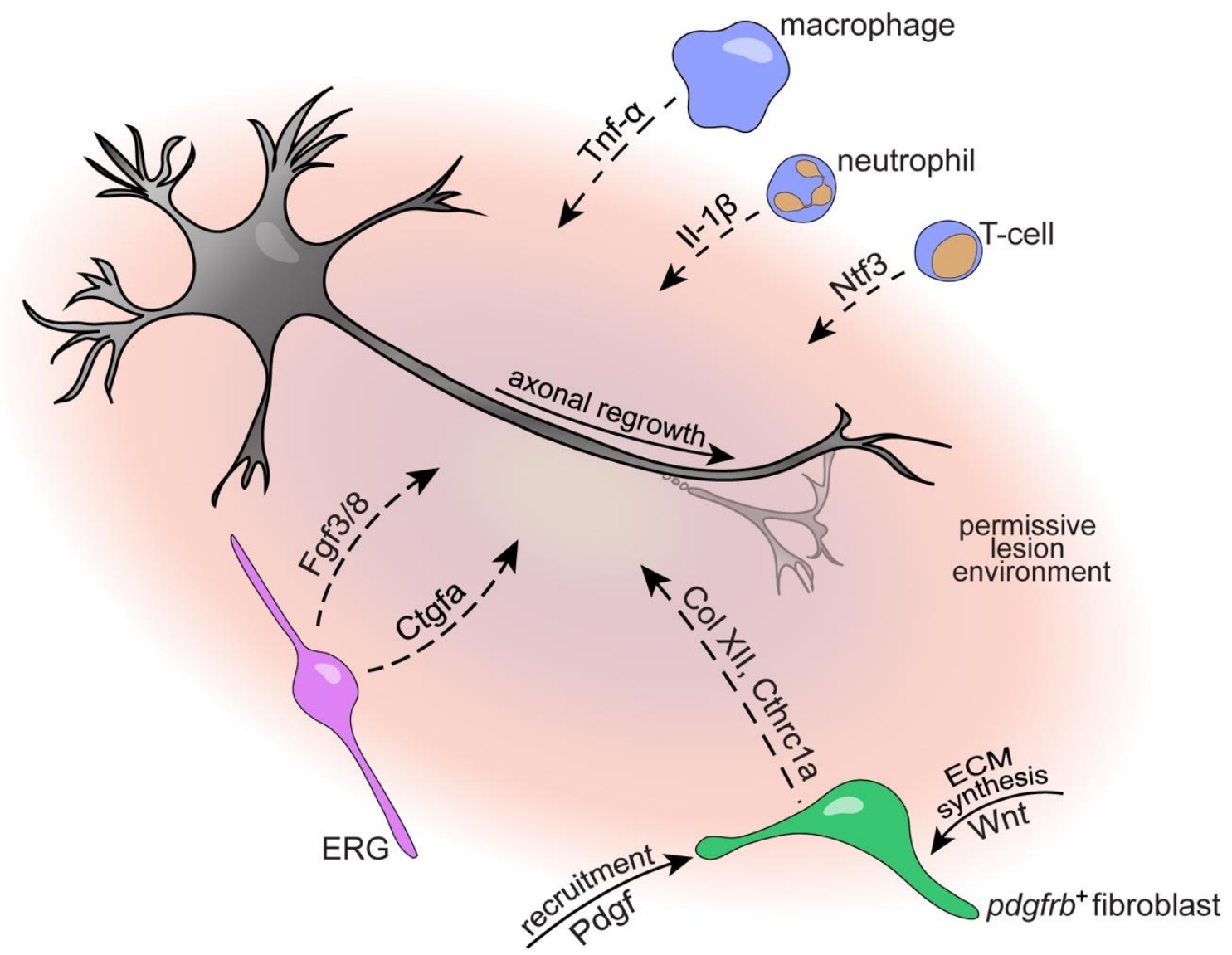

Figure 3. Key molecular and cellular players contributing to the axon growth-permissive lesion environment after SCI in zebrafish. ERGs secrete growth factors (Fgf, Ctgf), $p d g f r b^{+}$fibroblasts deposit growth-conducive ECM (Col XII, Cthrc1a) molecules and immune cells dynamically control inflammation promoting axon regeneration. The roles of individual cells and contributing factors are described in detail in the main text. Arrows indicate direct interaction of secreted factors with target cells, dashed arrows indicate indirect interaction or not shown to be direct. Abbreviations: Tnf-a, tumor necrosis factor $\alpha$; Il-1 $\beta$, interleukin-1 $\beta$; Ntf3, neurotrophin 3; ECM, extracellular matrix; $p d g f r b^{+}$, platelet-derived growth factor receptor $\beta$-positive; Col XII, collagen type XII; Cthrc1a, collagen triple helix repeat containing 1a; Pdgf, platelet-derived growth factor; ERG, ependymo-radial glia; Ctgfa, connective tissue growth factor; Fgf3/8, fibroblast growth factor $3 / 8$.

\subsection{Oligodendrocytes and Oligodendrocyte Progenitor Cells}

In addition to their function as insulators and their role in signal transduction through myelin wrapping, oligodendrocytes support axonal survival through structural, metabolic and trophic support [63-66]. Furthermore, oligodendrocyte progenitor cells (OPCs) communicate and interact with axons bidirectionally and dynamically throughout life via synaptic connections [67], allowing the modulation of OPC biology and myelination by neuronal activity [68,69]. Although OPCs are capable of myelination after SCI [70] and alleviation of locomotor deficits can occur in the absence of complete re-myelination [71], the insufficient replenishment of lost oligodendrocytes is considered a contributing impediment to axon regeneration after SCI. Although a significant loss of mature, myelinating oligodendrocytes is also observed after SCI in adult zebrafish, OPCs apparently largely survive the primary and secondary damage [38,40]. Importantly, OPCs differentiate to re-establish the oligodendrocyte population within two weeks post-injury and contribute to re-myelination of regenerated axonal fibres [38,40]. Negligible death of OPCs has also been reported after SCI in larval zebrafish [24], supporting the notion that cellular responses to SCI are conserved between larval and adult stages.

The formation of synaptic-like structures between presumptive OPCs ( $\mathrm{NG}^{+}$cells) and axonal terminals that entrap neurites and thereby halt their growth, represents an 
additional obstacle to mammalian CNS axon regeneration [72,73]. In addition, a variety of oligodendrocyte lineage-derived molecules, specifically myelin membrane bound proteins, including oligodendrocyte-myelin glycoprotein (OMgp), myelin-associated glycoprotein (MAG), neurite outgrowth inhibitor (Nogo) and chondroitin sulfate proteoglycans (CSPGs) such as NG2 (CSPG4), inhibit axonal regrowth by destabilizing growth cones that become dystrophic and eventually degenerate [74]. Interestingly, zebrafish Reticulon (Rtn)/Nogo family proteins appear to be less growth inhibitory, as axons of retinal ganglion cells regenerated successfully in the presence of the zebrafish ortholog Rtn $4 b$ in vitro and in vivo [75]. Furthermore, spinal cord transection leads to increased expression of the immunoglobulin superfamily molecule protein zero (P0), an important component of myelin formation in white matter axonal tracts, suggesting a prominent role for $\mathrm{P} 0$ in myelination and promotion of axon regeneration in zebrafish [76]. Concomitantly, transcriptional profiling of zebrafish OPCs revealed upregulation of genes coding for extracellular matrix (ECM) and ECM-remodeling enzymes after SCI, including connective tissue growth factor (ctgfa), semaphorin $3 c(s e m a 3 c)$ and tenascin-c $(t n c)$ but not inhibitory cspg4. This suggests a role for zebrafish OPCs in supporting axon regeneration by secreting growth-permissive ECM [40]. Together, these data point to a beneficial role of oligodendroglia lineage cells to axon regeneration after SCI in zebrafish (Figures 1 and 2). Future studies need to investigate how the cellular response of oligodendroglia lineage cells precisely affect axonal regrowth and signal propagation, key events for the functional restoration and fine coordination of locomotor activity after injury.

\subsection{The Glial Cell and Fibroblast Response to SCI}

The formation of an injury scar, often exhibiting fluid-filled cystic cavities [77,78], is a major barrier to axon regeneration across the lesion site in the mammalian CNS. Consisting of different regions with distinct cellular and molecular signatures [79,80], the scar is complex and involves a fibrous core in which invading fibroblasts deposit a dense meshwork of ECM that is inhibitory to axonal growth [81]. Surrounding the fibrous core, the glial component of the scar consist of reactive astrocytes, $\mathrm{NG}^{+}$presumptive OPCs and cells of the immune system that migrate to the lesion site upon activation [82]. Although scar formation is crucial in stabilizing the expansion and spread of uncontrolled tissue damage and inflammation [78] to ensure overall survival [83], and the extent to which astrocytes inhibit axon regeneration is currently debated [84], local tissue re-modelling creates a barrier to axonal regrowth [79] (Figure 1).

\subsubsection{Ependymo-Radial Glia}

The glial component of the scar in mammals is composed of cells of the ependymal niche, which are activated after injury, proliferate and generate scar-contributing astrocytes $[85,86]$. Although limiting secondary damage, glial cells are thought to produce inhibitory ECM molecules, including CSPGs [87]. In zebrafish, Glial fibrillary acidic protein $(\mathrm{GFAP})^{+}$astrocyte-like glia, which correspond to ependymo-radial glia (ERGs) that have their soma located at the central canal and extend radial processes that span the parenchyma, do not separate the injury site from the spared tissue (Figures 1 and 2). Instead, ERGs undergo a Hippo signaling-controlled and Twist1-mediated epithelial-tomesenchymal transition (EMT), elongate their processes and, together with regrowing axons, participate in the formation of the neural tissue bridge that reconnects the severed spinal cord $[26,31,88]$. As ERGs do not contribute to the formation of an injury scar, a body of research has focused on the identification of factors promoting glial bridging during regeneration of the zebrafish spinal cord. Yet, their specific role in axon regeneration has been subject to controversy. Glial bridges have been proposed to provide a substrate for regenerating axons to cross the lesion site [31]. Although a systematic ultrastructural analysis is lacking in zebrafish, live observations of glial and neuronal processes in larval animals [26], histological analysis in the eel [89] and ultrastructural analysis of the adult goldfish [90] provided evidence that axonal fascicles precede glial cells when navigating the lesion 
site. Importantly, axonal bridging was also established when $\mathrm{GFAP}^{+}$glia were selectively ablated using the NTR/MTZ system, indicating that glial bridging is dispensable for axonal regrowth across the spinal lesion site, at least in larval zebrafish [26]. Although, it remains to be demonstrated whether adult fish fully recapitulate the observations made in larvae, these data argue for a different function of glial cells in supporting axon regeneration in zebrafish. During development and homeostasis, glial cells are a major source of trophic factors that promote neuronal cell migration, growth and survival [91]. Indeed, after SCI in zebrafish a heterogeneous cell population, that includes ERGs, secretes Ctgfa and its loss in ctgfa mutants impaired axon regeneration and functional recovery; an effect that can be rescued by systemic over-expression of ctgfa or application of recombinant human CTGF [23]. However, as the cells that are competent to respond to Ctgfa by means of a ligand-receptor interaction are unknown, it remains to be investigated whether Ctgfa acts on neurons to promote axonal regrowth directly or indirectly through control of ECM deposition in the lesion site-a well-established function of CTGF in the context of injury $[92,93]$ (Figure 3). Similarly, ERGs and neurons secrete fibroblast growth factors (FGF) 3 and 8a [31] (Figure 3). FGF ligands presumably activate the FGF pathway in an autocrine manner as target genes (spry, pea3 and erm) are expressed in ERGs and neurons [31]. Systemic genetic or pharmacological interference with FGF signaling inhibited both glial and axonal bridging $[31,94]$. Thus, formation of a tissue bridge after SCI requires FGF pathway activity in neural cells. As cell type-specific manipulations can identify surprising complexity during tissue regeneration [95], future work using ERG-specific manipulations [26,96] could provide novel insight on a potential direct link between glial cell-derived molecular cues and axon regeneration.

\subsubsection{Fibroblasts}

The deposition of ECM by invading non-neural cells is considered a major contributor to the growth non-permissive injury scar that axons encounter upon CNS pathologies in mammals [97] (Figure 1). Perivascular cells have been identified as a primary source of scarforming fibroblasts after SCI $[98,99]$. Attenuating fibrosis by interference with fibroblast generation or migration [100-102], or depriving the lesion site of ECM components by inhibition of collagen biosynthesis and deposition [103,104] or enzymatic inactivation [105], enhances permissiveness of the scar. This underscores the fibrous scar as a target for therapeutic interventions after SCI.

Similar to mammals, fibroblasts infiltration and prominent ECM deposition have been described after SCI in zebrafish [26,106], goldfish [107] and other regenerating vertebrates [8]. In zebrafish, a fibroblast population of perivascular and myoseptal origin that enters the lesion site can be identified by the expression of the platelet-derived growth factor receptor (Pdgfr) $\beta$, similar to what has been described in the mouse spinal cord $[98,99]$. Thus, the initial cellular response to SCI appears to be largely conserved between zebrafish and non-regenerating vertebrates, although additional fibroblast subtypes likely exist in both species that contribute to the lesion site population [108]. Different to mammals however, in zebrafish, $p d g f r b^{+}$fibroblasts are required for axon regeneration and functional recovery while cell autonomous signaling through the Pdgf receptor (Pdgfr) has been identified as a molecular cue controlling their recruitment [106] (Figures 2 and 3). Interestingly, Pdgf signaling also appears to be a conserved chemoattractant for fibroblasts contributing to organ regeneration in other species [109]. Yet it is unknown whether signaling through the Pdgfr may identify a target for alleviating perivascular cell-derived scarring in mammals. The regeneration-promoting effect of zebrafish $p d g f r b^{+}$fibroblasts after SCI has been attributed to the secretion of a regeneration-permissive ECM that is enriched in growth-promoting (e.g., collagen type XII (Col XII), collagen triple-helix repeat containing 1a (Cthrc1a), Tenascin-C (TnC)) and deprived of growth-limiting matrix molecules (e.g., Lumican (Lum), Microfibril Associated Protein 2 (Mfap2), Periostin (Postn), collagen type IV (Col IV)) [106]. Thus, the specific composition of the fibroblast-derived ECM appears to define a key difference between zebrafish and mammalian fibroblast 
response and regenerative outcome upon SCI. Future studies will need to establish the detailed function of specific matrix components in promoting axonal regrowth in zebrafish as well as to systemically map the differences in ECM composition between regenerating and non-regenerating species. Although the cues controlling the composition of the fibroblast-derived ECM remain to be identified, Wnt/ $\$$-catenin (Wnt) signaling has already been shown to play a decisive role in zebrafish. Wnt signaling promotes regeneration in larval and adult zebrafish $[110,111]$ by acting on $p d g f r b^{+}$fibroblasts to control expression of pro-regenerative type XII collagen, which is necessary and sufficient for axon regeneration [26] (Figure 3). Interestingly, Wnt pathway activity in fibroblasts is required for both glial and axonal bridging, suggesting that glial cells and regrowing neurites utilize ECM as growth substrates to cross the lesion site [26].

Increasing evidence indicates that the injury scar exerts its inhibitory function on axonal regrowth not only through its biochemical composition but also acts as a mechanical barrier due to the altered elastic stiffness of the local microenvironment [112]. Indeed, axons interact with their environment not only chemically but also mechanically [113]. However, very little is known about the role of mechanical signals involved in axonal regrowth. Furthermore, the contribution of ECM to the mechanical properties of the lesion environment as well as that of local tissue mechanics to regenerative success remains poorly investigated. Recently, atomic force microscopy-enabled nanoindentation revealed a stiffening of the zebrafish spinal cord during regeneration, which contrasts the compliant signature of the growth-inhibitory scar tissue found in mammalian CNS lesions [114]. Future studies investigating the differences in mechanical properties of the lesion environment between regenerating and non-regenerating species as well as the identification of their determinants will reveal previously unappreciated neuron-extrinsic factors contributing to regeneration success versus inhibitory scarring. Such information will aid the development of biomaterial-scaffold strategies used to stimulate axon regeneration after SCI in mammals.

\section{Intrinsic Regenerative Capacity}

In addition to the regeneration barrier created by the hostile lesion environment, a battery of neuron-intrinsic molecular pathways, that are active during development yet fail to reactivate and initiate a successful growth response after injury, determine the limited capacity of mammalian axons to regrow [115].

SCI disrupts axonal homeostasis due to physical and metabolic perturbations. These include rupture of the axon plasma membrane, rapid elevation of intra-axonal $\mathrm{Ca}^{2+}$ concentration, destabilization of actin and microtubule cytoskeletal network and disorganization of intra-axonal organelles. In mammals, these events do not result in the activation of geneexpression programs necessary for growth cone formation and neurite extension [116,117]. In contrast, in the zebrafish CNS, axotomy-induced signals are successfully translated into a regeneration response. The upregulation of the major vault protein $(m v p)$, constituent of the ribonucleoprotein complex, during the acute phase after SCI has been proposed as a potential regulator of cell survival under conditions of cellular stress, acting as an anti-apoptotic factor [118]. In mop null mutant zebrafish cell death was enhanced after SCI, although little effect on axon regeneration could be observed. Surprisingly, mop knockdown by use of morpholino oligonucleotides was reported to perturb axonal regrowth and functional recovery, suggesting a direct role of Mvp protein for successful axon regeneration [119]. Future studies will need to clarify the precise function of Mvp in spinal cord regeneration. The levels of activating transcription factor 6 (atf6), a type-II transmembrane protein in the endoplasmic reticulum and a major stress sensor, as well as its target genes binding immunoglobulin protein (bip) and C/EBP homologous transcription factor protein (chop), were also tightly regulated after SCI in adult zebrafish. atf6 knockdown inhibited axon regeneration and delayed recovery of swimming activity, suggesting a role for endoplasmatic reticulum homeostasis to axonal protection and regeneration [120]. Furthermore, brainstem and intraspinal neurons upregulate cell recognition and guidance molecules such as 
Growth Associated Protein 43 (GAP-43), L1.1, L1.2 and Semaphorin 4D, all of which support axon regeneration and functional recovery $[22,28,121]$. Intriguingly, the upregulation of growth-promoting molecules depended also on the distance of the lesion to the neuronal soma, highlighting an intrinsic spatially-controlled regulation of axon regeneration [28]. Similarly, the proximity of the injury site to the soma determines the regeneration of the Mauthner axon. Regrowth occurs following injuries between $10 \%$ and $50 \%$ of the total axon length but is very poor when axotomy is located both close as well as distant to the soma [34]. Regeneration capacity of the Mauthner axon could be enhanced by increasing cyclic adenosine monophosphate (cAMP) levels and mitochondrial transport [36,122], highlighting cellular energetics as a strategy to promote axonal regrowth and functional recovery after SCI $[123,124]$. The initiation of sprouting, as well as the selection of the optimal trajectory to establish functional synapses, is of crucial importance for successful pathfinding and functional axon regeneration. Indeed, in the larval and adult zebrafish, regenerating axons grow through novel pathways, including the grey matter $[26,29,47]$. Interestingly, experiments in axotomized Mauthner axons revealed that axons cross the lesion site by first initiating multidirectional sprouting and then correcting their route in a ubiquitin ligase Pam/Highwire/Rpm-1 (PHR)-dependent manner. This process was largely dependent on the tight regulation of actin polymerization by cytoplasmic FMR1 interacting protein 2 (Cyfip2) and c-Jun N-terminal kinase (JNK) signaling pathways [125], implicating growth cone extension for axon regeneration. While knowledge on intrinsic pro-regenerative factors in spinal-projecting neurons is still limited, previous studies on the optic nerve, which likewise robustly regenerates in zebrafish, have resulted in additional insights and are reviewed in detail elsewhere [52].

\section{Conclusions and Outlook}

Zebrafish have greatly advanced our understanding on the cellular interactions and molecular mechanisms directing successful axon regeneration in the spinal cord (Summarized in Table 1). Yet much remains to be understood. Conditional, cell type-specific manipulations are imperative to dissect the contribution of the complex neural and nonneural cell responses to the lesion environment and axon regeneration. The transgenesis amenability that zebrafish offer and the recent technological advances that allow for conditional gene inactivation [126], cell type-specific inducible gene expression [127-129], optogenetic manipulations [46,106], single cell RNA sequencing [130], large-scale genetic lineage tracing [131] and advanced optical techniques for in vivo-mapping of mechanical tissue properties [132] provide an optimal platform to characterize cellular relationships and contribution of different factors to spinal cord regeneration. Furthermore, the zebrafish SCI larval model is amenable to small molecule in vivo screens [133], which in combination with high-throughput, automated imaging and analysis platforms [134], can greatly accelerate the identification of potential targets to foster functional recovery after SCI in non-regenerating vertebrates. Finally, interspecies comparison on the multi-omics scale will be instrumental to map the differences that hamper regeneration in mammals yet facilitate functional recovery in zebrafish and other regenerating vertebrates [88,135]. We expect that future findings will provide exciting insight on what enables some vertebrates to successfully regenerate their CNS axons and recover locomotor function after injury. 


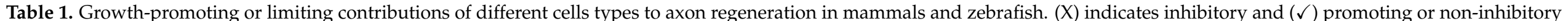

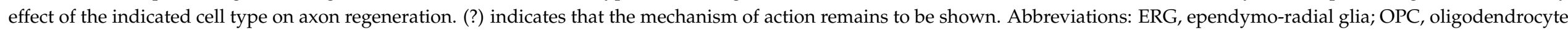
progenitor cell; ECM, extracellular matrix.

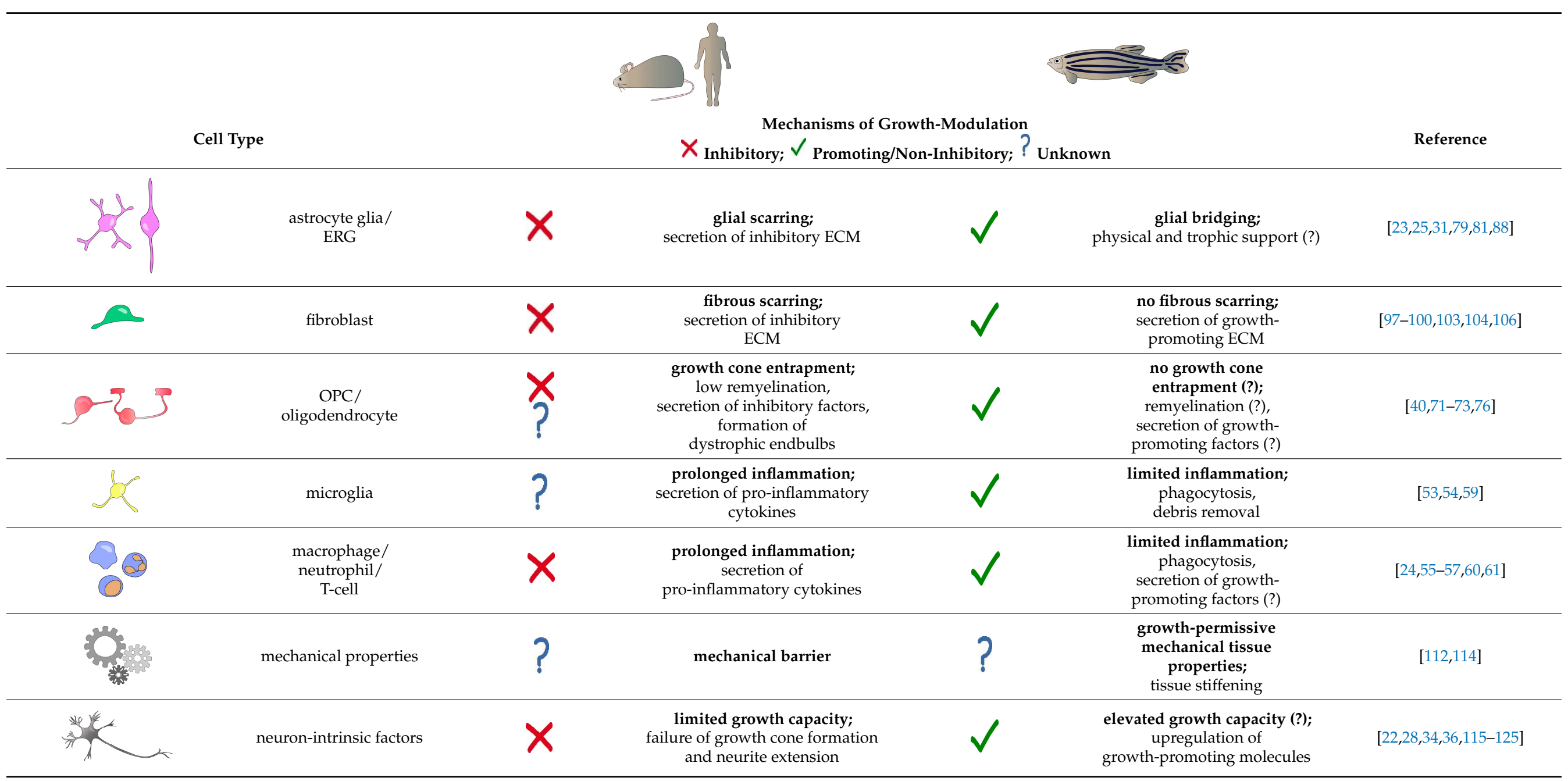


Author Contributions: Conceptualization, V.T. and D.W.; writing-original draft: V.T. and D.W.; writing-review and editing, V.T. and D.W.; visualization, V.T. and D.W. All authors have read and agreed to the published version of the manuscript.

Funding: V.T. acknowledges support from the Greek State Scholarships Foundation (IK $\Upsilon$ ) (cofinanced by Greece and the European Union (European Social Fund-ESF) through the Operational Program «Human Resources Development, Education and Lifelong Learning» in the context of the project "Reinforcement of Postdoctoral Researchers-2nd Cycle" (MIS-5033021).

Institutional Review Board Statement: Not applicable.

Informed Consent Statement: Not applicable.

Data Availability Statement: Not applicable.

Acknowledgments: We thank Julia Kolb, Nora John, Stephanie Möllmert, Eoghan O'Connell, Catherina $\mathrm{G}$. Becker and Thomas Becker for critical reading of the manuscript.

Conflicts of Interest: The authors declare no conflict of interest.

\section{References}

1. McDonald, J.W.; Sadowsky, C. Spinal-cord injury. Lancet 2002, 359, 417-425.

2. Boulland, J.-L.; Lambert, F.M.; Züchner, M.; Ström, S.; Glover, J.C. A Neonatal Mouse Spinal Cord Injury Model for Assessing Post-Injury Adaptive Plasticity and Human Stem Cell Integration. PLoS ONE 2013, 8, e71701. [CrossRef]

3. Züchner, M.; Kondratskaya, E.; Sylte, C.B.; Glover, J.C.; Boulland, J. Rapid recovery and altered neurochemical dependence of locomotor central pattern generation following lumbar neonatal spinal cord injury. J. Physiol. 2018, 596, 281-303. [CrossRef]

4. Fry, E.J.; Stolp, H.B.; Lane, M.A.; Dziegielewska, K.M.; Saunders, N.R. Regeneration of supraspinal axons after complete transection of the thoracic spinal cord in neonatal opossums (Monodelphis domestica). J. Comp. Neurol. 2003, 466, $422-444$. [CrossRef] [PubMed]

5. Hasan, S.J.; Nelson, B.H.; Valenzuela, J.I.; Keirstead, H.S.; Shull, S.E.; Ethell, D.W.; Steeves, J.D. Functional repair of transected spinal cord in embryonic chick. Restor. Neurol. Neurosci. 1991, 2, 137-154. [CrossRef] [PubMed]

6. $\quad$ Edwards-Faret, G.; González-Pinto, K.; Cebrián-Silla, A.; Peñailillo, J.; García-Verdugo, J.M.; Larraín, J. Cellular response to spinal cord injury in regenerative and non-regenerative stages in Xenopus laevis. Neural Dev. 2021, 16, 2. [CrossRef]

7. Streeter, K.; Sunshine, M.; Brant, J.; Sandoval, A.G.W.; Maden, M.; Fuller, D.D. Molecular and histologic outcomes following spinal cord injury in spiny mice, Acomys cahirinus. J. Comp. Neurol. 2019, 528, 1535-1547. [CrossRef]

8. A Zukor, K.; Kent, D.T.; Odelberg, S.J. Meningeal cells and glia establish a permissive environment for axon regeneration after spinal cord injury in newts. Neural Dev. 2011, 6, 1. [CrossRef]

9. Mchedlishvili, L.; Epperlein, H.H.; Telzerow, A.; Tanaka, E.M. A clonal analysis of neural progenitors during axolotl spinal cord regeneration reveals evidence for both spatially restricted and multipotent progenitors. Development 2007, 134, 2083-2093. [CrossRef]

10. Yamada, H.; Miyake, T.; Kitamura, T. Regeneration of Axons in Transection of the Carp Spinal Cord. Zool. Sci. 1995, 12, 325-332. [CrossRef]

11. Doyle, L.; Stafford, P.; Roberts, B. Recovery of locomotion correlated with axonal regeneration after a complete spinal transection in the eel. Neuroscience 2001, 107, 169-179. [CrossRef]

12. Sobrido-Cameán, D.; Robledo, D.; Romaus-Sanjurjo, D.; Pérez-Cedrón, V.; Sánchez, L.; Rodicio, M.C.; Barreiro-Iglesias, A. Inhibition of Gamma-Secretase Promotes Axon Regeneration After a Complete Spinal Cord Injury. Front. Cell Dev. Biol. 2020, 8 , 173. [CrossRef] [PubMed]

13. Hanslik, K.L.; Allen, S.R.; Harkenrider, T.L.; Fogerson, S.M.; Guadarrama, E.; Morgan, J.R. Regenerative capacity in the lamprey spinal cord is not altered after a repeated transection. PLoS ONE 2019, 14, e0204193. [CrossRef]

14. Bernstein, J.J. Relation of spinal cord regeneration to age in adult goldfish. Exp. Neurol. 1964, 9, 161-174. [CrossRef]

15. Becker, T.; Wullimann, M.F.; Becker, C.; Bernhardt, R.R.; Schachner, M. Axonal regrowth after spinal cord transection in adult zebrafish. J. Comp. Neurol. 1997, 377, 577-595. [CrossRef]

16. Kroehne, V.; Freudenreich, D.; Hans, S.; Kaslin, J.; Brand, M. Regeneration of the adult zebrafish brain from neurogenic radial glia-type progenitors. Development 2011, 138, 4831-4841. [CrossRef]

17. Fausett, B.V.; Goldman, D. A Role for $\alpha 1$ Tubulin-Expressing Muller Glia in Regeneration of the Injured Zebrafish Retina. J. Neurosci. 2006, 26, 6303-6313. [CrossRef]

18. Bernhardt, R.; Tongiorgi, E.; Anzini, P.; Schachner, M. Increased expression of specific recognition molecules by retinal ganglion cells and by optic pathway glia accompanies the successful regeneration of retinal axons in adult zebrafish. J. Comp. Neurol. 1996, 376, 253-264. [CrossRef]

19. Thummel, R.; Kassen, S.C.; Montgomery, J.E.; Enright, J.M.; Hyde, D.R. Inhibition of Müller glial cell division blocks regeneration of the light-damaged zebrafish retina. Dev. Neurobiol. 2007, 68, 392-408. [CrossRef] 
20. Cigliola, V.; Becker, C.J.; Poss, K.D. Building bridges, not walls: Spinal cord regeneration in zebrafish. Dis. Model. Mech. 2020, 13, 044131. [CrossRef]

21. Becker, C.G.; Becker, T. Neuronal Regeneration from Ependymo-Radial Glial Cells: Cook, Little Pot, Cook! Dev. Cell 2015, 32, 516-527. [CrossRef] [PubMed]

22. Becker, C.; Lieberoth, B.C.; Morellini, F.; Feldner, J.; Becker, T.; Schachner, M. L1.1 Is Involved in Spinal Cord Regeneration in Adult Zebrafish. J. Neurosci. 2004, 24, 7837-7842. [CrossRef] [PubMed]

23. Mokalled, M.H.; Patra, C.; Dickson, A.L.; Endo, T.; Stainier, D.; Poss, K.D. Injury-induced ctgfa directs glial bridging and spinal cord regeneration in zebrafish. Science 2016, 354, 630-634. [CrossRef] [PubMed]

24. Ohnmacht, J.; Yang, Y.-J.; Maurer, G.W.; Barreiro-Iglesias, A.; Tsarouchas, T.M.; Wehner, D.; Sieger, D.; Becker, C.G.; Becker, T. Spinal motor neurons are regenerated after mechanical lesion and genetic ablation in larval zebrafish. Dev. 2016, 143, 1464-1474. [CrossRef] [PubMed]

25. Briona, L.K.; Dorsky, R.I. Radial glial progenitors repair the zebrafish spinal cord following transection. Exp. Neurol. 2014, 256, 81-92. [CrossRef]

26. Wehner, D.; Tsarouchas, T.M.; Michael, A.; Haase, C.; Weidinger, G.; Reimer, M.M.; Becker, T.; Becker, C.G. Wnt signaling controls pro-regenerative Collagen XII in functional spinal cord regeneration in zebrafish. Nat. Commun. 2017, 8, 1-17. [CrossRef]

27. Kuscha, V.; Barreiro-Iglesias, A.; Becker, C.; Becker, T. Plasticity of tyrosine hydroxylase and serotonergic systems in the regenerating spinal cord of adult zebrafish. J. Comp. Neurol. 2012, 520, 933-951. [CrossRef]

28. Becker, T.; Bernhardt, R.R.; Reinhard, E.; Wullimann, M.F.; Tongiorgi, E.; Schachner, M. Readiness of Zebrafish Brain Neurons to Regenerate a Spinal Axon Correlates with Differential Expression of Specific Cell Recognition Molecules. J. Neurosci. 1998, 18, 5789-5803. [CrossRef]

29. Becker, T.; Becker, C.G. Regenerating descending axons preferentially reroute to the gray matter in the presence of a general macrophage/microglial reaction caudal to a spinal transection in adult zebrafish. J. Comp. Neurol. 2001, 433, 131-147. [CrossRef] [PubMed]

30. Becker, T.; Lieberoth, B.C.; Becker, C.; Schachner, M. Differences in the regenerative response of neuronal cell populations and indications for plasticity in intraspinal neurons after spinal cord transection in adult zebrafish. Mol. Cell. Neurosci. 2005, 30, 265-278. [CrossRef]

31. Goldshmit, Y.; Sztal, T.E.; Jusuf, P.R.; Hall, T.E.; Nguyen-Chi, M.; Currie, P.D. Fgf-Dependent Glial Cell Bridges Facilitate Spinal Cord Regeneration in Zebrafish. J. Neurosci. 2012, 32, 7477-7492. [CrossRef] [PubMed]

32. Thiele, T.; Donovan, J.C.; Baier, H. Descending Control of Swim Posture by a Midbrain Nucleus in Zebrafish. Neuron 2014, 83, 679-691. [CrossRef]

33. Vasudevan, D.; Liu, Y.-C.; Barrios, J.P.; Wheeler, M.K.; Douglass, A.D.; Dorsky, R.I. Regenerated interneurons integrate into locomotor circuitry following spinal cord injury. Exp. Neurol. 2021, 342, 113737. [CrossRef] [PubMed]

34. Hecker, A.; Anger, P.; Braaker, P.N.; Schulze, W.; Schuster, S. High-resolution mapping of injury-site dependent functional recovery in a single axon in zebrafish. Commun. Biol. 2020, 3, 1-12. [CrossRef]

35. Hu, B.-B.; Chen, M.; Huang, R.-C.; Huang, Y.-B.; Xu, Y.; Yin, W.; Li, L. In vivo imaging of Mauthner axon regeneration, remyelination and synapses re-establishment after laser axotomy in zebrafish larvae. Exp. Neurol. 2018, 300, 67-73. [CrossRef]

36. Bhatt, D.H.; Otto, S.J.; DePoister, B.; Fetcho, J.R.; Leist, M.; Ghezzi, P.; Grasso, G.; Bianchi, R.; Villa, P.; Fratelli, M.; et al. Cyclic AMP-Induced Repair of Zebrafish Spinal Circuits. Science 2004, 305, 254-258. [CrossRef]

37. Hecker, A.; Schulze, W.; Oster, J.; Richter, D.O.; Schuster, S. Removing a single neuron in a vertebrate brain forever abolishes an essential behavior. Proc. Natl. Acad. Sci. USA 2020, 117, 3254-3260. [CrossRef] [PubMed]

38. Reimer, M.M.; Sörensen, I.; Kuscha, V.; Frank, R.E.; Liu, C.; Becker, C.G.; Becker, T. Motor Neuron Regeneration in Adult Zebrafish J. Neurosci. 2008, 28, 8510-8516. [CrossRef]

39. Wehner, D.; Becker, T.; Becker, C.G. Restoration of anatomical continuity after spinal cord transection depends on Wnt/ $\beta$-catenin signaling in larval zebrafish. Data Brief 2018, 16, 65-70. [CrossRef] [PubMed]

40. Tsata, V.; Kroehne, V.; Wehner, D.; Rost, F.; Lange, C.; Hoppe, C.; Kurth, T.; Reinhardt, S.; Petzold, A.; Dahl, A.; et al. Reactive oligodendrocyte progenitor cells (re-)myelinate the regenerating zebrafish spinal cord. Development 2020, 147. [CrossRef]

41. Briona, L.K.; Dorsky, R.I. Spinal Cord Transection in the Larval Zebrafish. J. Vis. Exp. 2014, 2014, e51479. [CrossRef] [PubMed]

42. Gollmann-Tepeköylü, C.; Nägele, F.; Graber, M.; Pölzl, L.; Lobenwein, D.; Hirsch, J.; An, A.; Irschick, R.; Röhrs, B.; Kremser, C.; et al. Shock waves promote spinal cord repair via TLR3. JCI Insight 2020, 5. [CrossRef] [PubMed]

43. Zeng, C.-W.; Kamei, Y.; Shigenobu, S.; Sheu, J.-C.; Tsai, H.-J. Injury-induced Cavl-expressing cells at lesion rostral side play major roles in spinal cord regeneration. Open Biol. 2021, 11, 200304. [CrossRef]

44. Hui, S.P.; Dutta, A.; Ghosh, S. Cellular response after crush injury in adult zebrafish spinal cord. Dev. Dyn. 2010, 239, 2962-2979. [CrossRef]

45. Curado, S.; Anderson, R.M.; Jungblut, B.; Mumm, J.; Schroeter, E.; Stainier, D. Conditional targeted cell ablation in zebrafish: A new tool for regeneration studies. Dev. Dyn. 2007, 236, 1025-1035. [CrossRef]

46. Mruk, K.; Ciepla, P.; Piza, P.A.; Alnaqib, M.A.; Chen, J.K. Targeted cell ablation in zebrafish using optogenetic transcriptional control. Development 2020, 147, 183640. [CrossRef] [PubMed]

47. Anguita-Salinas, C.; Sánchez, M.; Morales, R.A.; Ceci, M.L.; Rojas-Benítez, D.; Allende, M.L. Cellular Dynamics during Spinal Cord Regeneration in Larval Zebrafish. Dev. Neurosci. 2019, 41, 112-122. [CrossRef] 
48. Sagasti, A.; O’Brien, G.S.; Rieger, S.; Martin, S.M.; Cavanaugh, A.M.; Portera-Cailliau, C. Two-photon axotomy and time-lapse confocal imaging in live zebrafish embryos. J. Vis. Exp. 2009, 2009, e1129. [CrossRef]

49. Sahu, S.; Zhang, Z.; Li, R.; Hu, J.; Shen, H.; Loers, G.; Shen, Y.; Schachner, M. A Small Organic Compound Mimicking the L1 Cell Adhesion Molecule Promotes Functional Recovery after Spinal Cord Injury in Zebrafish. Mol. Neurobiol. 2017, 55, 859-878. [CrossRef]

50. Grossman, S.; Rosenberg, L.; Wrathall, J. Temporal-Spatial Pattern of Acute Neuronal and Glial Loss after Spinal Cord Contusion. Exp. Neurol. 2001, 168, 273-282. [CrossRef]

51. Fitch, M.T.; Silver, J. CNS injury, glial scars, and inflammation: Inhibitory extracellular matrices and regeneration failure. Exp. Neurol. 2008, 209, 294-301. [CrossRef]

52. Becker, T.; Becker, C.G. Axonal regeneration in zebrafish. Curr. Opin. Neurobiol. 2014, 27, 186-191. [CrossRef] [PubMed]

53. Yang, L.; Jones, N.R.; Blumbergs, P.C.; Heuvel, C.V.D.; Moore, E.J.; Manavis, J.; Sarvestani, G.T.; Ghabriel, M.N. Severitydependent expression of pro-inflammatory cytokines in traumatic spinal cord injury in the rat. J. Clin. Neurosci. 2005, 12, 276-284. [CrossRef] [PubMed]

54. Pineau, I.; Lacroix, S. Proinflammatory cytokine synthesis in the injured mouse spinal cord: Multiphasic expression pattern and identification of the cell types involved. J. Comp. Neurol. 2007, 500, 267-285. [CrossRef]

55. Beck, K.D.; Nguyen, H.X.; Galvan, M.D.; Salazar, D.L.; Woodruff, T.; Anderson, A.J. Quantitative analysis of cellular inflammation after traumatic spinal cord injury: Evidence for a multiphasic inflammatory response in the acute to chronic environment. Brain 2010, 133, 433-447. [CrossRef] [PubMed]

56. Ekdahl, C.T.; Claasen, J.-H.; Bonde, S.; Kokaia, Z.; Lindvall, O. Inflammation is detrimental for neurogenesis in adult brain. Proc. Natl. Acad. Sci. USA 2003, 100, 13632-13637. [CrossRef]

57. Tsarouchas, T.M.; Wehner, D.; Cavone, L.; Munir, T.; Keatinge, M.; Lambertus, M.; Underhill, A.; Barrett, T.; Kassapis, E.; Ogryzko, N.; et al. Dynamic control of proinflammatory cytokines Il-1 $\beta$ and Tnf- $\alpha$ by macrophages in zebrafish spinal cord regeneration. Nat. Commun. 2018, 9, 1-17. [CrossRef]

58. Nelson, C.M.; Lennon, V.A.; Lee, H.; Krug, R.G., 2nd; Kamalova, A.; Madigan, N.N.; Clark, K.J.; Windebank, A.J.; Henley, J.R. Glucocorticoids Target Ependymal Glia and Inhibit Repair of the Injured Spinal Cord. Front.Cell Dev. Biol. 2019, 7, 56. [CrossRef]

59. Hilla, A.M.; Diekmann, H.; Fischer, D. Microglia Are Irrelevant for Neuronal Degeneration and Axon Regeneration after Acute Injury. J. Neurosci. 2017, 37, 6113-6124. [CrossRef]

60. Keatinge, M.; Tsarouchas, T.M.; Munir, T.; Porter, N.J.; Larraz, J.; Gianni, D.; Tsai, H.-H.; Becker, C.G.; Lyons, D.A.; Becker, T. CRISPR gRNA phenotypic screening in zebrafish reveals pro-regenerative genes in spinal cord injury. PLoS Genet. 2021, 17, e1009515. [CrossRef]

61. Hui, S.P.; Sheng, D.Z.; Sugimoto, K.; Gonzalez-Rajal, A.; Nakagawa, S.; Hesselson, D.; Kikuchi, K. Zebrafish Regulatory T Cells Mediate Organ-Specific Regenerative Programs. Dev. Cell 2017, 43, 659-672.e5. [CrossRef]

62. Huie, J.R.; Ferguson, A.R.; Kyritsis, N.; Pan, J.Z.; Irvine, K.-A.; Nielson, J.L.; Schupp, P.G.; Oldham, M.C.; Gensel, J.C.; Lin, A.; et al. Machine intelligence identifies soluble TNFa as a therapeutic target for spinal cord injury. Sci. Rep. 2021, 11, 1-11. [CrossRef] [PubMed]

63. Griffiths, I.; Klugmann, M.; Anderson, T.; Yool, D.; Thomson, C.; Schwab, M.H.; Schneider, A.; Zimmermann, F.; McCulloch, M.; Nadon, N.; et al. Axonal Swellings and Degeneration in Mice Lacking the Major Proteolipid of Myelin. Science 1998, 280, 1610-1613. [CrossRef]

64. Fünfschilling, U.; Supplie, L.M.; Mahad, D.; Boretius, S.; Saab, A.S.; Edgar, J.; Brinkmann, B.G.; Kassmann, C.M.; Tzvetanova, I.D.; Möbius, W.; et al. Glycolytic oligodendrocytes maintain myelin and long-term axonal integrity. Nature 2012, 485, 517-521. [CrossRef] [PubMed]

65. Lee, Y.; Morrison, B.M.; Li, Y.; Lengacher, S.; Farah, M.H.; Hoffman, P.N.; Liu, Y.; Tsingalia, A.; Jin, L.; Zhang, P.-W.; et al. Oligodendroglia metabolically support axons and contribute to neurodegeneration. Nat. Cell Biol. 2012, 487, 443-448. [CrossRef] [PubMed]

66. Larson, V.A.; Mironova, Y.; Vanderpool, K.G.; Waisman, A.; Rash, J.E.; Agarwal, A.; Bergles, D.E. Oligodendrocytes control potassium accumulation in white matter and seizure susceptibility. eLife 2018, 7, 7. [CrossRef] [PubMed]

67. Bergles, D.E.; Roberts, J.D.B.; Somogyi, P.; Jahr, C.E. Glutamatergic synapses on oligodendrocyte precursor cells in the hippocampus. Nat. Cell Biol. 2000, 405, 187-191. [CrossRef] [PubMed]

68. Gibson, E.M.; Purger, D.; Mount, C.W.; Goldstein, A.K.; Lin, G.; Wood, L.S.; Inema, I.; Miller, S.E.; Bieri, G.; Zuchero, J.B.; et al. Neuronal Activity Promotes Oligodendrogenesis and Adaptive Myelination in the Mammalian Brain. Science 2014, 344, 1252304. [CrossRef]

69. Mensch, S.; Baraban, M.; Almeida, R.; Czopka, T.; Ausborn, J.; El Manira, A.; Lyons, D. Synaptic vesicle release regulates myelin sheath number of individual oligodendrocytes in vivo. Nat. Neurosci. 2015, 18, 628-630. [CrossRef] [PubMed]

70. Assinck, P.; Duncan, G.J.; Plemel, J.R.; Lee, M.; Stratton, J.A.; Manesh, S.B.; Liu, J.; Ramer, L.M.; Kang, S.H.; Bergles, D.E.; et al. Myelinogenic Plasticity of Oligodendrocyte Precursor Cells following Spinal Cord Contusion Injury. J. Neurosci. 2017, 37, 8635-8654. [CrossRef] [PubMed]

71. Duncan, G.J.; Manesh, S.B.; Hilton, B.; Assinck, P.; Liu, J.; Moulson, A.; Plemel, J.R.; Tetzlaff, W. Locomotor recovery following contusive spinal cord injury does not require oligodendrocyte remyelination. Nat. Commun. 2018, 9, 1-16. [CrossRef] [PubMed] 
72. Filous, A.R.; Tran, A.; Howell, C.J.; Busch, S.A.; Evans, T.A.; Stallcup, W.B.; Kang, S.H.; Bergles, D.E.; Lee, S.-I.; Levine, J.M.; et al. Entrapment via Synaptic-Like Connections between NG2 Proteoglycan+ Cells and Dystrophic Axons in the Lesion Plays a Role in Regeneration Failure after Spinal Cord Injury. J. Neurosci. 2014, 34, 16369-16384. [CrossRef] [PubMed]

73. Dou, C.; Levine, J. Inhibition of neurite growth by the NG2 chondroitin sulfate proteoglycan. J. Neurosci. 1994, 14, 7616-7628. [CrossRef] [PubMed]

74. Schwab, M.E.; Strittmatter, S.M. Nogo limits neural plasticity and recovery from injury. Curr. Opin. Neurobiol. 2014, 27, 53-60. [CrossRef] [PubMed]

75. Bodrikov, V.; Welte, C.; Wiechers, M.; Weschenfelder, M.; Kaur, G.; Shypitsyna, A.; Pinzon-Olejua, A.; Bastmeyer, M.; Stuermer, C.A.O. Substrate properties of zebrafish Rtn $4 \mathrm{~b} / \mathrm{Nogo}$ and axon regeneration in the zebrafish optic nerve. J. Comp. Neurol. 2017, 525, 2991-3009. [CrossRef] [PubMed]

76. Becker, T.; Becker, C.; Schachner, M. Expression of protein zero is increased in lesioned axon pathways in the central nervous system of adult zebrafish. Glia 2003, 41,301-317. [CrossRef]

77. Hong, L.T.A.; Kim, Y.-M.; Park, H.H.; Hwang, D.H.; Cui, Y.; Lee, E.M.; Yahn, S.; Lee, J.K.; Song, S.-C.; Kim, B.G. An injectable hydrogel enhances tissue repair after spinal cord injury by promoting extracellular matrix remodeling. Nat. Commun. 2017, 8, 1-14. [CrossRef]

78. Kwiecien, J.M.; Dabrowski, W.; Dąbrowska-Bouta, B.; Sulkowski, G.; Oakden, W.; Kwiecien-Delaney, C.J.; Yaron, J.R.; Zhang, L.; Schutz, L.; Marzec-Kotarska, B.; et al. Prolonged inflammation leads to ongoing damage after spinal cord injury. PLoS ONE 2020, 15, e0226584. [CrossRef] [PubMed]

79. Bradbury, E.J.; Burnside, E.R. Moving beyond the glial scar for spinal cord repair. Nat. Commun. 2019, 10, 1-15. [CrossRef]

80. Adams, K.L.; Gallo, V. The diversity and disparity of the glial scar. Nat. Neurosci. 2018, 21, 9-15. [CrossRef]

81. Tran, A.P.; Warren, P.M.; Silver, J. The Biology of Regeneration Failure and Success After Spinal Cord Injury. Physiol. Rev. 2018, 98, 881-917. [CrossRef]

82. O'Shea, T.M.; Burda, J.E.; Sofroniew, M.V. Cell biology of spinal cord injury and repair. J. Clin. Investig. 2017, 127, 3259-3270. [CrossRef] [PubMed]

83. Faulkner, J.R.; Herrmann, J.E.; Woo, M.J.; Tansey, K.E.; Doan, N.B.; Sofroniew, M.V. Reactive Astrocytes Protect Tissue and Preserve Function after Spinal Cord Injury. J. Neurosci. 2004, 24, 2143-2155. [CrossRef]

84. Anderson, M.A.; Ao, Y.; Sofroniew, M.V. Heterogeneity of reactive astrocytes. Neurosci. Lett. 2014, 565, 23-29. [CrossRef] [PubMed]

85. Barnabé-Heider, F.; Göritz, C.; Sabelström, H.; Takebayashi, H.; Pfrieger, F.W.; Meletis, K.; Frisén, J. Origin of new glial cells in intact and injured adult spinal cord. Cell Stem Cell 2010, 7, 470-482. [CrossRef]

86. Meletis, K.; Barnabé-Heider, F.; Carlén, M.; Evergren, E.; Tomilin, N.; Shupliakov, O.; Frisén, J. Spinal Cord Injury Reveals Multilineage Differentiation of Ependymal Cells. PLoS Biol. 2008, 6, e182. [CrossRef]

87. Jones, L.L.; Margolis, R.U.; Tuszynski, M.H. The chondroitin sulfate proteoglycans neurocan, brevican, phosphacan, and versican are differentially regulated following spinal cord injury. Exp. Neurol. 2003, 182, 399-411. [CrossRef]

88. Shaw, D.K.; Saraswathy, V.M.; Zhou, L.; McAdow, A.R.; Burris, B.; Butka, E.; Morris, S.A.; Dietmann, S.; Mokalled, M.H. Localized EMT reprograms glial progenitors to promote spinal cord repair. Dev. Cell 2021, 56, 613-626.e7. [CrossRef] [PubMed]

89. Dervan, A.G.; Roberts, B.L. Reaction of spinal cord central canal cells to cord transection and their contribution to cord regeneration. J. Comp. Neurol. 2003, 458, 293-306. [CrossRef] [PubMed]

90. Nona, S.N.; Stafford, C.A. Gliali repair at the lesion site in regenerating goldfish spinal cord: An immunohistochemical study using species-specific antibodies. J. Neurosci. Res. 1995, 42, 350-356. [CrossRef] [PubMed]

91. Verkhratsky, A.; Matteoli, M.; Parpura, V.; Mothet, J.; Zorec, R. Astrocytes as secretory cells of the central nervous system: Idiosyncrasies of vesicular secretion. EMBO J. 2016, 35, 239-257. [CrossRef]

92. Conrad, S.; Schluesener, H.J.; Adibzahdeh, M.; Schwab, J.M. Spinal cord injury induction of lesional expression of profibrotic and angiogenic connective tissue growth factor confined to reactive astrocytes, invading fibroblasts and endothelial cells. J. Neurosurg. Spine 2005, 2, 319-326. [CrossRef]

93. Wang, Y.; Kong, Q.-J.; Sun, J.-C.; Yang, Y.; Wang, H.-B.; Zhang, Q.; Shi, J.-G. Lentivirus-mediated silencing of the CTGF gene suppresses the formation of glial scar tissue in a rat model of spinal cord injury. Spine J. 2018, 18, 164-172. [CrossRef]

94. Goldshmit, Y.; Tang, J.K.K.Y.; Siegel, A.L.; Nguyen, P.; Kaslin, J.; Currie, P.D.; Jusuf, P.R. Different Fgfs have distinct roles in regulating neurogenesis after spinal cord injury in zebrafish. Neural Dev. 2018, 13, 24. [CrossRef] [PubMed]

95. Wehner, D.; Cizelsky, W.; Vasudevaro, M.D.; Ozhan, G.; Haase, C.; Kagermeier-Schenk, B.; Röder, A.; Dorsky, R.I.; Moro, E.; Argenton, F.; et al. Wnt/ $\beta$-catenin signaling defines organizing centers that orchestrate growth and differentiation of the regenerating zebrafish caudal fin. Cell Rep. 2014, 6, 467-481.

96. Cavone, L.; McCann, T.; Drake, L.K.; Aguzzi, E.A.; Oprişoreanu, A.-M.; Pedersen, E.; Sandi, S.; Selvarajah, J.; Tsarouchas, T.M.; Wehner, D.; et al. A unique macrophage subpopulation signals directly to progenitor cells to promote regenerative neurogenesis in the zebrafish spinal cord. Dev. Cell 2021. [CrossRef]

97. Dias, D.O.; Göritz, C. Fibrotic scarring following lesions to the central nervous system. Matrix Biol. 2018, 68-69, 561-570. [CrossRef]

98. Göritz, C.; Dias, D.O.; Tomilin, N.; Barbacid, M.; Shupliakov, O.; Frisén, J. A Pericyte Origin of Spinal Cord Scar Tissue. Science 2011, 333, 238-242. 
99. Soderblom, C.; Luo, X.; Blumenthal, E.; Bray, E.; Lyapichev, K.; Ramos, J.; Krishnan, V.; Lai-Hsu, C.; Park, K.K.; Tsoulfas, P.; et al. Perivascular Fibroblasts Form the Fibrotic Scar after Contusive Spinal Cord Injury. J. Neurosci. 2013, 33, 13882-13887. [CrossRef] [PubMed]

100. Dias, D.O.; Kim, H.; Holl, D.; Solnestam, B.W.; Lundeberg, J.; Carlén, M.; Göritz, C.; Frisén, J. Reducing Pericyte-Derived Scarring Promotes Recovery after Spinal Cord Injury. Cell 2018, 173, 153-165.e22. [CrossRef]

101. Hellal, F.; Hurtado, A.; Ruschel, J.; Flynn, K.C.; Laskowski, C.J.; Umlauf, M.; Kapitein, L.C.; Strikis, D.; Lemmon, V.; Bixby, J.; et al. Microtubule Stabilization Reduces Scarring and Causes Axon Regeneration after Spinal Cord Injury. Science 2011, 331, 928-931. [CrossRef]

102. Ruschel, J.; Hellal, F.; Flynn, K.C.; Dupraz, S.; Elliott, D.A.; Tedeschi, A.; Bates, M.; Sliwinski, C.; Brook, G.; Dobrindt, K.; et al. Systemic administration of epothilone B promotes axon regeneration after spinal cord injury. Science 2015, 348, 347-352. [CrossRef]

103. Stichel, C.C.; Hermanns, S.; Luhmann, H.J.; Lausberg, F.; Niermann, H.; D’Urso, D.; Servos, G.; Hartwig, H.-G.; Müller, H.W. Inhibition of collagen IV deposition promotes regeneration of injured CNS axons. Eur. J. Neurosci. 1999, 11, 632-646. [CrossRef] [PubMed]

104. Klapka, N.; Hermanns, S.; Straten, G.; Masanneck, C.; Duis, S.; Hamers, F.P.T.; Müller, D.; Zuschratter, W.; Müller, H.W. Suppression of fibrous scarring in spinal cord injury of rat promotes long-distance regeneration of corticospinal tract axons, rescue of primary motoneurons in somatosensory cortex and significant functional recovery. Eur. J. Neurosci. 2005, 22, 3047-3058 [CrossRef] [PubMed]

105. Bradbury, E.J.; Moon, L.; Popat, R.J.; King, V.R.; Bennett, G.S.; Patel, P.N.; Fawcett, J.W.; McMahon, S.B. Chondroitinase ABC promotes functional recovery after spinal cord injury. Nat. Cell Biol. 2002, 416, 636-640. [CrossRef]

106. Tsata, V.; Möllmert, S.; Schweitzer, C.; Kolb, J.; Möckel, C.; Böhm, B.; Rosso, G.; Lange, C.; Lesche, M.; Hammer, J.; et al. A switch in pdgfrb cell-derived ECM composition prevents inhibitory scarring and promotes axon regeneration in the zebrafish spinal cord. Dev. Cell 2021, 56, 509-524.e9. [CrossRef] [PubMed]

107. Hirsch, S.; Cahill, M.A.; Stuermer, C.A.O. Fibroblasts at the transection site of the injured goldfish optic nerve and their potential role during retinal axonal regeneration. J. Comp. Neurol. 1995, 360, 599-631. [CrossRef]

108. Muhl, L.; Genové, G.; Leptidis, S.; Liu, J.; He, L.; Mocci, G.; Sun, Y.; Gustafsson, S.; Buyandelger, B.; Chivukula, I.V.; et al. Single-cell analysis uncovers fibroblast heterogeneity and criteria for fibroblast and mural cell identification and discrimination. Nat. Commun. 2020, 11, 3953. [CrossRef]

109. Currie, J.D.; Kawaguchi, A.; Traspas, R.M.; Schuez, M.; Chara, O.; Tanaka, E.M. Live Imaging of Axolotl Digit Regeneration Reveals Spatiotemporal Choreography of Diverse Connective Tissue Progenitor Pools. Dev. Cell 2016, 39, 411-423. [CrossRef] [PubMed]

110. Strand, N.S.; Hoi, K.K.; Phan, T.M.; Ray, C.A.; Berndt, J.D.; Moon, R.T. Wnt/ $\beta$-catenin signaling promotes regeneration after adult zebrafish spinal cord injury. Biochem. Biophys. Res. Commun. 2016, 477, 952-956. [CrossRef]

111. Briona, L.K.; Poulain, F.E.; Mosimann, C.; Dorsky, R.I. Wnt/ $B$-catenin signaling is required for radial glial neurogenesis following spinal cord injury. Dev. Biol. 2015, 403, 15-21. [CrossRef]

112. Moeendarbary, E.; Weber, I.P.; Sheridan, G.K.; Koser, D.E.; Soleman, S.; Haenzi, B.; Bradbury, E.; Fawcett, J.; Franze, K. The soft mechanical signature of glial scars in the central nervous system. Nat. Commun. 2017, 8, 14787. [CrossRef]

113. Koser, D.; Thompson, A.J.; Foster, S.K.; Dwivedy, A.; Pillai, E.; Sheridan, G.K.; Svoboda, H.; Viana, M.; Costa, L.D.F.; Guck, J.; et al. Mechanosensing is critical for axon growth in the developing brain. Nat. Neurosci. 2016, 19, 1592-1598. [CrossRef]

114. Möllmert, S.; Kharlamova, M.A.; Hoche, T.; Taubenberger, A.V.; Abuhattum, S.; Kuscha, V.; Kurth, T.; Brand, M.; Guck, J. Zebrafish Spinal Cord Repair Is Accompanied by Transient Tissue Stiffening. Biophys. J. 2020, 118, 448-463. [CrossRef]

115. Cho, Y.; Sloutsky, R.; Naegle, K.M.; Cavalli, V. Injury-Induced HDAC5 Nuclear Export Is Essential for Axon Regeneration. Cell 2013, 155, 894-908. [CrossRef]

116. Plunet, W.; Kwon, B.K.; Tetzlaff, W. Promoting axonal regeneration in the central nervous system by enhancing the cell body response to axotomy. J. Neurosci. Res. 2002, 68, 1-6. [CrossRef]

117. Park, K.K.; Liu, K.; Hu, Y.; Smith, P.D.; Wang, C.; Cai, B.; Xu, B.; Connolly, L.; Kramvis, I.; Sahin, M.; et al. Promoting Axon Regeneration in the Adult CNS by Modulation of the PTEN/mTOR Pathway. Sci. 2008, 322, 963-966. [CrossRef]

118. Zhang, X.; Yang, Y.; Bu, X.; Wei, Y.; Lou, X. The major vault protein is dispensable for zebrafish organ regeneration. Heliyon 2020, 6, e05422. [CrossRef] [PubMed]

119. Pan, H.-C.; Lin, J.-F.; Ma, L.-P.; Shen, Y.-Q.; Schachner, M. Major vault protein promotes locomotor recovery and regeneration after spinal cord injury in adult zebrafish. Eur. J. Neurosci. 2012, 37, 203-211. [CrossRef] [PubMed]

120. Ji, Z.; Zhou, Z.-L.; Hao, Q.; Zhao, L.; Cui, C.; Huang, S.-B.; Yang, Y.-L.; Shen, Y.-Q. Activating Transcription Factor 6 Contributes to Functional Recovery After Spinal Cord Injury in Adult Zebrafish. J. Mol. Neurosci. 2021, 71, 734-745. [CrossRef] [PubMed]

121. Peng, S.-X.; Yao, L.; Cui, C.; Zhao, H.-D.; Liu, C.-J.; Li, Y.-H.; Wang, L.-F.; Huang, S.-B.; Shen, Y.-Q. Semaphorin4D promotes axon regrowth and swimming ability during recovery following zebrafish spinal cord injury. Neuroscience 2017, 351, 36-46. [CrossRef]

122. Xu, Y.; Chen, M.; Hu, B.; Huang, R.; Hu, B. In vivo Imaging of Mitochondrial Transport in Single-Axon Regeneration of Zebrafish Mauthner Cells. Front. Cell. Neurosci. 2017, 11, 4. [CrossRef] [PubMed] 
123. Han, Q.; Xie, Y.; Ordaz, J.D.; Huh, A.J.; Huang, N.; Wu, W.; Liu, N.; Chamberlain, K.A.; Sheng, Z.-H.; Xu, X.-M. Restoring Cellular Energetics Promotes Axonal Regeneration and Functional Recovery after Spinal Cord Injury. Cell Metab. 2020, 31, 623-641.e8. [CrossRef] [PubMed]

124. Yang, L.-Q.; Chen, M.; Ren, D.-L.; Hu, B. Dual Oxidase Mutant Retards Mauthner-Cell Axon Regeneration at an Early Stage via Modulating Mitochondrial Dynamics in Zebrafish. Neurosci. Bull. 2020, 36, 1500-1512. [CrossRef]

125. Bremer, J.; Marsden, K.C.; Miller, A.; Granato, M. The ubiquitin ligase PHR promotes directional regrowth of spinal zebrafish axons. Commun. Biol. 2019, 2, 195. [CrossRef]

126. Hans, S.; Zöller, D.; Hammer, J.; Stucke, J.; Spieß, S.; Kesavan, G.; Kroehne, V.; Eguiguren, J.S.; Ezhkova, D.; Petzold, A.; et al. Cre-Controlled CRISPR mutagenesis provides fast and easy conditional gene inactivation in zebrafish. Nat. Commun. 2021, 12, 1125. [CrossRef]

127. Wehner, D.; Jahn, C.; Weidinger, G. Use of the TetON System to Study Molecular Mechanisms of Zebrafish Regeneration. J. Vis. Exp. 2015, 2015, e52756. [CrossRef] [PubMed]

128. Knopf, F.; Schnabel, K.; Haase, C.; Pfeifer, K.; Anastassiadis, K.; Weidinger, G. Dually inducible TetON systems for tissue-specific conditional gene expression in zebrafish. Proc. Natl. Acad. Sci. USA 2010, 107, 19933-19938. [CrossRef]

129. Campbell, L.J.; Willoughby, J.J.; Jensen, A.M. Two Types of Tet-On Transgenic Lines for Doxycycline-Inducible Gene Expression in Zebrafish Rod Photoreceptors and a Gateway-Based Tet-On Toolkit. PLoS ONE 2012, 7, e51270. [CrossRef]

130. Lange, C.; Rost, F.; Machate, A.; Reinhardt, S.; Lesche, M.; Weber, A.; Kuscha, V.; Dahl, A.; Rulands, S.; Brand, M. Single cell sequencing of radial glia progeny reveals diversity of newborn neurons in the adult zebrafish brain. Development 2020, 147, 1855951. [CrossRef] [PubMed]

131. Raj, B.; Wagner, D.E.; McKenna, A.; Pandey, S.; Klein, A.M.; Shendure, J.; Gagnon, J.A.; Schier, A.F. Simultaneous single-cell profiling of lineages and cell types in the vertebrate brain. Nat. Biotechnol. 2018, 36, 442-450. [CrossRef]

132. Schlüßler, R.; Möllmert, S.; Abuhattum, S.; Cojoc, G.; Müller, P.; Kim, K.; Möckel, C.; Zimmermann, C.; Czarske, J.; Guck, J. Mechanical Mapping of Spinal Cord Growth and Repair in Living Zebrafish Larvae by Brillouin Imaging. Biophys. J. 2018, 115, 911-923. [CrossRef] [PubMed]

133. Chapela, D.; Sousa, S.; Martins, I.; Cristóvão, A.M.; Pinto, P.; Corte-Real, S.; Saúde, L. A zebrafish drug screening platform boosts the discovery of novel therapeutics for spinal cord injury in mammals. Sci. Rep. 2019, 9, 1-12. [CrossRef] [PubMed]

134. Early, J.J.; Marshall-Phelps, K.L.; Williamson, J.M.; Swire, M.; Kamadurai, H.; Muskavitch, M.; Lyons, D.A. An automated high-resolution in vivo screen in zebrafish to identify chemical regulators of myelination. eLife 2018, 7, e35136. [CrossRef]

135. Tica, J.; Didangelos, A. Comparative Transcriptomics of Rat and Axolotl After Spinal Cord Injury Dissects Differences and Similarities in Inflammatory and Matrix Remodeling Gene Expression Patterns. Front. Neurosci. 2018, 12, 808. [CrossRef] [PubMed] 